\title{
Assessing Interdependencies Between Food and Energy Prices: The Case of Biodiesel in Germany
}

\author{
Zuzana Lajdová, Jaroslav Kapusta, Peter Bielik \\ Faculty of Economics and Management, University of Agriculture in Nitra, Slovakia
}

\begin{abstract}
The paper aims to analyse the relationship between energy prices (biodiesel, crude oil) and food commodities - vegetable oils used also as feedstock for biodiesel production. The econometric technique of price transmission, such as unit root test, cointegration test and vector error correction model, is applied to assess the interdependencies between energy prices and vegetable oil prices in Germany. Results suggest close price linkages between prices of vegetable oils and biodiesel and confirm that the vegetable oil prices drive the price dynamics of biodiesel. However, the simultaneous relationship is only revealed between biodiesel and soybean oil prices. The increase in crude oil prices is found to lead to an upward trend in the vegetable oils used for biodiesel production, thus influencing biodiesel prices as well.
\end{abstract}

\section{Keywords}

Biodiesel, crude oil, food, Germany, price transmission.

Lajdová, Z., Kapusta, J. and Bielik, P. (2017) “Assessing Interdependencies Between Food and Energy Prices: The Case of Biodiesel in Germany", AGRIS on-line Papers in Economics and Informatics, Vol. 9, No. 3, pp. 51 - 59. ISSN 1804-1930. DOI 10.7160/aol.2017.090305.

\section{Introduction}

The fuel and energy crises of the late 1970's and early 1980's and concerns about the depletion of the world's non-renewable resources as well as increased environmental problems provided the incentives to look for alternatives to petroleumbased fuels (Knothe et al., n.d.). There are several reasons for biofuels (i.e. security reasons, environmental concerns, foreign exchange savings, and socioeconomic issues related to the rural sector) to be considered as relevant replacement for fossil liquid fuels (Demirbas, 2008). A 'first generation' biofuel (i.e. biodiesel (bio-esters), bio-ethanol, and biogas) is characterized either by its ability to be blended with petroleum-based fuels, combusted in existing internal combustion engines, and distributed through existing infrastructure, or by the use in existing alternative vehicle technology like FFVs ("Flexible Fuel Vehicle") or natural gas vehicles (Naik, et al., 2010). Blanco et al. (2010) explain that the biofuel yield per hectare of first generation biofuels varies greatly between feedstocks and producing areas, and follows the trade-offs between crop yield per hectare and the energy yield of specific crops. Additionally, biofuels production costs can vary widely by feedstock, conversion process, scale of production and region but the cost of feedstock is a major component of overall costs, e.g. the cost of feedstock for biodiesel production is about $75-80 \%$ of the total operating cost (Demirbas, 2009).

Biodiesel has been considered a promising option as an eco-friendly alternative to diesel fuel largely utilized in the transport, agriculture, commercial, domestic and industrial sectors for the generation of power/mechanical energy (Barnwal and Sharma, 2005). Shereena and Thangaraj (2009) determine the following general advantages of biodiesel: (1) lower dependence on crude oil, (2) renewable fuel, (3) favourable energy balance, (4) reduction in greenhouse gas emission, (5) lower harmful emission, (6) biodegradable and non-toxic, (7) the use of agricultural surplus, and (8) safer handling (higher flash point than conventional diesel fuel). The feedstock for biodiesel production can be categorized as lipid feedstock and alcohol feedstock. The lipid feedstock includes vegetable oils, animal fats, and, more recently, other plant-like organisms such as micro algae and cyanobacteria; however vegetable oils are currently the major sources for making biodiesel (Issariyakul and Dalai, 2014). The primary production of biodiesel is concentrated in Europe (Germany 
is the leading European biodiesel producer) with rapeseed oil as the major source. Soybean oil is another lipid feedstock used for synthesis of biodiesel in Brazil and U.S and palm oil is used in biodiesel production as the major input in Malaysia (Yu et al., 2006).

There are concerns about adverse effects of first generation biofuels, including the impact they may have on biodiversity and land use and competition with food crops. The issue of biofuel-food correlation came to be examined carefully and a research on a possible impacts of biofuels on food prices has become more frequent (Capitani, 2014). Peri and Baldi (2010) analyse correlations between vegetable oil prices and conventional diesel prices in the European Union between 2005 and 2007. The results reveal a two-regime threshold cointegration model only for rapeseed oil - diesel price pair and indicate that the adjustment process of rapeseed oil prices is fast to its long-run equilibrium, but asymmetric, thus rapeseed oil appears particularly exposed to external shocks deriving from global political scenarios such as given the high quota of EU biodiesel produced by this vegetable oil. Later on, Kristoufek et al. (2012) analyse the relationship between biodiesel and related fuels and commodity prices in the US and Germany from 2003 to 2011 with the use of minimal spanning trees and hierarchical trees and confirm that biofuel is affected by food and fuel prices. However, biofuel prices show limited capacity to determine food prices. Additionally, the evidence of a strong impact of crude oil prices on biodiesel prices, and of biodiesel prices on rapeseed oil prices was found by Busse et al. (2010). Hassouneh et al. (2012) using a multivariate local linear regression model and a parametric error correction model assess price linkages among biodiesel, sunflower and crude oil prices in Spain, finding the existence of a long-run equilibrium relationship between the three prices. Lajdova et al. (2015) analyse long run relationship between biofuel prices and food commodity prices in US with the use of vector error correction model and find out the presence of bilateral causality between biodiesel and soybean prices. Hao et al. (2013) use cointegration test between biodiesel and soybean and find also a long-run relationship between the prices. Busse and Ihle (2009) study the price linkages between rapeseed oil, soy oil and biodiesel in German market during the period 2002-2007 applying a Markov switching vector error correction model (MS-VECM) and find an evidence of a weakening adjustment process provided when prices diverge from their longrun equilibrium prices after 2005, particularly for rapeseed oil prices.

Bentivoglio et al. (2014) note that current research has mainly concentrated on the US and Brazilian ethanol markets; however, the European biodiesel market has not received much concern. Therefore, the paper intends to provide a comprehensive analysis of price relationship between vegetable oils, used as a feedstock for biodiesel production, and energy prices (crude oil and biodiesel) in order to gain better insight of interacting price behavior in the EU biodiesel market. Our research contributes to the biofuel and food price debate and the results might help producers and traders of vegetable oils to plan their business operations as well as provide government with information regarding policy formulation.

The paper aims to analyse the relationship between energy prices (biodiesel, crude oil) and food commodities - vegetable oils used also as feedstock for biodiesel production.

\section{Materials and methods}

The main goal of the paper is to investigate the relationship between biodiesel price and relevant agricultural commodities - vegetable oils used for biodiesel production. Crude oil as relevant natural substitute of biodiesel is included as well. The analysis is based on monthly observations covering period from January 2006 to December 2014. Average monthly wholesale biodiesel price was taken from The Union for Promotion of Oil and Protein Plants (UFOP). We use the German prices as Germany has been one of the most important biodiesel producers in the world. Rapeseed oil prices were downloaded from UFOP as well, soybean oil, palm oil and crude oil prices were taken from Index Mundi. The logarithmic transformations of data were taken - logarithmic prices facilitate interpretation of results since coefficients correspond to percentage changes, thus can be interpreted as a price elasticity (Serra et al., 2011). The paper also provides the description of recent price dynamics of the above mentioned variables as well as introduces the evolving policy context of the biodiesel production in Germany.

According to Bentivoglio and Rasetti (2015), the biofuel-related price transmission literature has focused on studying price level links using cointegration analysis and VECM (Vector Error Correction Model). Thus, in order to examine 
the existence of long-run relationship between selected variables, the analytical framework was set up based on applying the cointegration and vector error correction estimation procedure. In general, regression models for non-stationary variables give biased and inconsistent results and lead to spurious regression (Kristoufek et al., 2013). A technical prerequisite for cointegration analysis is that all variables are non-stationary. This condition is tested by Augmented Dickey-Fuller (ADF) test (Bakhat and Würzburg, 2013). The null hypothesis of ADF test is that series contains a unit root and ADF test shows whether the variables are stationary or nonstationary in the first differences and in levels (Ciaian and Kancs, 2011; Hassouneh et al., 2011). The ADF can be expressed as testing $\mathrm{H}_{0}: \alpha_{0}=0$ against $\mathrm{H}_{1}: \alpha_{0}<0$ from the following general model used by Capitani (2014):

$\Delta y_{t}=\alpha+\beta_{t}+\eta y_{t-1}+\sum_{i-1}^{p-1} \phi i \Delta y_{t-1}+e_{t}$

where $y_{t}$ is the variable assessed; $\alpha$ refers to a constant; $\beta$ is the coefficient on a time trend; $p$ is the lag order of the autoregressive process; and $e_{t}$ is the stochastic term named white noise. If time series are non-stationary in levels, but stationary in first differences, cointegration techniques may be applied. An optimal number of lags according to Akaike information criterion for providing Johansen test is determined in VAR space (Burakov, 2017). The Johansen test for cointegration evaluates the rank $(r)$ of the matrix $\Pi$. If $r=0$, all variables are $I$ (1) and not cointegrated. In case $0<r<N$, there exist $r$ cointegrating vectors. If $r=N$ all the variables are $I(0)$ and thus stationary, and any combination of stationary variables will be stationary. Johansen cointegration test is based on the following trace test and maximum eigenvalue test (Natanelov et al., 2013):

$$
\begin{aligned}
& \lambda_{\text {trace }}=-T \sum_{i=r+1}^{n} \ln \left(1-\hat{\lambda}_{i}^{2}\right), \\
& \lambda_{\max }(r, r+1)=-T \ln \left(1-\lambda_{r+1}\right),
\end{aligned}
$$

where $r$ is the number of cointegrated vectors and is the estimated value for the $\mathrm{i}^{\text {th }}$ order eigenvalue from the $\Pi$ matrix and $T$ is the total time period (Jena, 2016).

If the existence of the cointegration relation is found, a following form of vector error correction model (VECM) is estimated:

$$
\Delta P_{t}=\mu+\alpha \beta^{\prime} P_{t-1}+\Gamma_{1} \Delta P_{t-1}
$$

$$
+\Gamma_{2} \Delta P_{t-2}+\cdots+\Gamma_{k} \Delta P_{t-k}+\varepsilon_{t}
$$

where $\beta$ is known as the cointegration vector and shows the long run relationship between the prices and $\beta^{\prime} P_{t-1}$ is the disequilibrium error indicating the deviation of the price relationship from the long run equilibrium. $\alpha$ represents adjustment speed and refers to the percentage of disequilibrium error that would be corrected in each period. $P_{t}$ is a $r \times 1$ vector with its elements the price series under investigation at time $t, \mu$ refers to $r \times 1$ intercept vector, $\varepsilon_{t}$ is the error vector and $k$ represents the number of lags of the series (Chen and Saghaian, 2015). VECM estimates both short-run price dynamics and the adjustment of individual prices to deviations from the cointegration relationship (Hassouneh et al., 2012).

\section{Results and discussion}

Busse et al. (2010) explain that the use of vegetable oil as fuel was unregulated until 2003 in Germany. Later on, the growth of the biodiesel industry was mainly encouraged by investment assistance and tax exemptions granted since 2004. However, the situation changed in August 2006 when an energy tax of $103 \mathrm{EUR} / \mathrm{t}$ of biodiesel sold as B100 (pure biodiesel), and a full taxation (541 EUR/t) for biodiesel used in blends were implemented. As noted by Pires and Schechtman (2010), under the new legislation, biofuels face the same specific taxes as fossil fuels, with the exemptions replaced by discounts to be requested from the government after sale. The discounts given to biofuels used in blends were abolished in 2007, while discounts for pure biodiesel were progressively reduced (38.04 ct/1 in 2006, from $20132.14 \mathrm{ct} / \mathrm{l})$. According to the Biofuels Quota Act (in force since January 2007), that sets a minimum level of biofuels that must be used in road transport in Germany, the total biofuels quota for 2009 was 5,25\% rising to $6.25 \%$ based on energy content since 2010. Since January 2015, the quota has no longer been calculated on the basis of calorific value. As a result, the biofuels quota has been replaced by a climate protection quota, which will specify the minimum net contribution that must be made by biofuels to the reduction of GHG emissions and it will be increased to $7 \%$ by 2020 (International Energy Agency, 2015).

Recently, the oil price shock was observed during the period June 2014 - March 2015 when prices dropped down significantly with the main decrease after September 2014. The second biggest annual 
loss since trading started in the 1980s was recorded from June 2014 to December 2014 - OPEC contributed to the dramatic fall in prices because of refusing to cut oil production despite of huge global oversupply. The decline in crude oil prices has led to a downward trend in diesel fuel prices and affected the vegetable oils used for biodiesel production, thus influencing biodiesel economics as well. Regarding vegetable oils, the prices continued the downward trend in 2014/15 that was shown during 2013/14. The sharp drop down in vegetable oil prices was caused by ample global oilseed supply in 2014. During much of the observed period, soybean oil prices were above palm oil prices and rapeseed oil prices (Figure 1).

Correlation analysis reveals positive and strong correlation between crude oil and vegetable oil prices. Also biodiesel and oil prices are positively and significantly correlated. It means that the null hypothesis that the two variables are linearly independent or uncorrelated is rejected for all performed cases (Table 1). The price of biodiesel has a high correlation with crude oil, indicating that the demand linkage between the variables is at least as important as the cost structure linkage between the feedstock - vegetable oils and biodiesel. Also, there is a high correlation among the commodity prices: rapeseed oil and soybean oil $76 \%$, rapeseed oil and palm oil almost $70 \%$, soybean oil and palm oil almost $90 \%$.

Augmented Dickey Fuller (ADF) test is conducted in order to test the null hypothesis of a unit root in the price series against alternative of a stationary time series. The test confirms the presence of a unit root in all examined price series. The number of lags is determined by Hannan-Quinn information criterion, Akaike information criterion and Schwarz Bayesian information criterion. The results suggest an optimal lag order of 1 (Table 2).

Johansen co-integration test is performed for detecting the co-integration rank $\mathrm{r}$. The seasonal dummies are included in order to capture seasonality in the data (time plot of the series indicates some seasonal fluctuations). Based on the results, a long

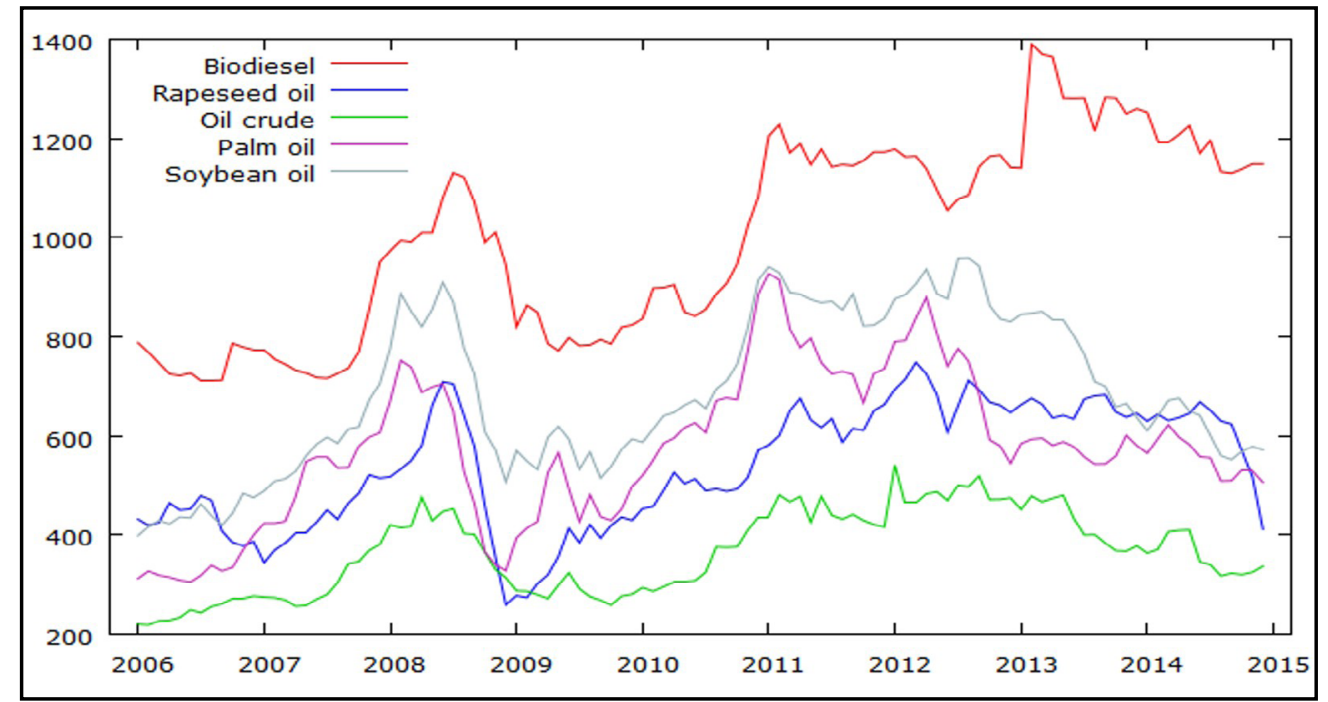

Source: own processing based on UFOP and Index Mundi

Figure 1: Development of biodiesel, crude oil prices (EUR/ 1000 l) and vegetable oil prices (EUR/t) during 2006-2015.

\begin{tabular}{|c|c|c|c|c|c|}
\hline $\begin{array}{l}\text { Correlation } \\
\text { coefficients }\end{array}$ & Biodiesel & Crude oil & Rapeseed oil & Soybean oil & Palm oil \\
\hline Biodiesel & 1.00 & 0.7954 & 0.8263 & 0.6956 & 0.5708 \\
\hline Crude oil & & 1.00 & 0.8133 & 0.9446 & 0.8009 \\
\hline Rapeseed oil & & & 1.00 & 0.7600 & 0.6691 \\
\hline Soybean oil & & & & 1.00 & 0.8977 \\
\hline Palm oil & & & & & 1.00 \\
\hline
\end{tabular}

Source: own processing 


\begin{tabular}{l|c|c|c|c|c|c}
\hline \multirow{2}{*}{ Price } & \multicolumn{2}{|c|}{ Test without constant } & \multicolumn{2}{c|}{ Test with constant } & \multicolumn{2}{c}{ Test with constant and trend } \\
\cline { 2 - 7 } & Level & FD & Level & FD & Level & FD \\
\hline Biodiesel & 0.415698 & $-6.41107^{* * *}$ & -1.51986 & $-6.43773^{* * *}$ & -2.39879 & $-6.42126^{* * *}$ \\
Crude oil & 0.0858165 & $-7.12354^{* * *}$ & -1.92475 & $-7.10979 * * *$ & $-1,33064$ & $-7.24073^{* * *}$ \\
Rapeseed oil & -0.612710 & $-4.43556^{* * *}$ & -2.26777 & $-4.40357 * * *$ & -2.19810 & $-4.45211^{* * *}$ \\
Soybean oil & -0.177199 & $-5.83148^{* * *}$ & -2.04070 & $-5.80956^{* * *}$ & -1.58641 & $-5.95635^{* * *}$ \\
Palm oil & -0.359486 & $-6.54082^{* * *}$ & -2.44671 & $-6.52029^{* * *}$ & -2.27196 & $-6.61664^{* * *}$ \\
\hline
\end{tabular}

Notes: FD: First difference; *** significant at $1 \%$ level

Source: own processing

Table 2: ADF test results for prices of biodiesel, crude oil and agricultural commodities.

\begin{tabular}{lcccc}
\hline \multirow{2}{*}{ Variables } & \multicolumn{2}{c}{ L- max test } & \multicolumn{2}{c}{ Trace test } \\
\cline { 2 - 5 } & $\mathbf{r}=\mathbf{0}$ & $\mathbf{r}=\mathbf{1}$ & $\mathbf{r}=\mathbf{0}$ & $\mathbf{r}=\mathbf{1}$ \\
\hline Biodiesel - Rapeseed oil & 20.164 & $2.6996^{* * *}$ & 22.863 & $2.6996^{* * *}$ \\
Biodiesel - Soybean oil & 21.252 & $8.2790^{* *}$ & 29.531 & $8.2790^{* *}$ \\
Biodiesel - Palm oil & 17.096 & $0.0090163^{* * *}$ & 17.105 & $0.0090163^{* * *}$ \\
Crude oil- Rapeseed oil & 12.774 & $0.00015955^{* * *}$ & 12.774 & $0.00015955^{* * *}$ \\
Crude oil- Soybean oil & 38.093 & $3.4245^{* *}$ & 41.517 & $3.4245^{* *}$ \\
Crude oil - Palm oil & 34.095 & $6.6663^{* * *}$ & 40.761 & $6.6663^{* * *}$ \\
\hline
\end{tabular}

Notes: $\mathrm{r}=0$ - no co-integration relationship; $\mathrm{r}=1-$ at most one co-integration relationship; $* * *$ significance at $1 \%$ level, ** significance at $5 \%$ level Source: own processing

Table 3: Results of Johansen co-integration test for prices of biodiesel and agricultural commodities; and prices of crude oil and agricultural commodities.

run relationship is confirmed among the majority of selected variables (Table 3 ).

The co-integration relationship is statistically significant, the constant and the adjustment coefficients $\alpha$ referring to vegetable oils are also statistically significant at $1 \%$ level in all examined equations ${ }^{1}$. Parameters $\alpha$ have the same sign for each tested pair variables representing that nonprofit relationship do not exist in all three price equations. Biodiesel prices adjust more rapidly to the long-run equilibrium than the examined vegetable oils. In case of biodiesel prices, $14.80 \%$ of the disequilibrium error is corrected in the equation with 1_rapeseed_oil, $12.20 \%$ is corrected in the equation with 1_soybean_oil and 10.20\% is corrected in the equation with $1 \_$palm_oil. On the other hand, only $2.64 \%, 8.79 \%$ and $5 . \overline{5} 1 \%$ are corrected for rapeseed oil, soybean oil and palm oil. Furthermore, vegetable oil prices seem to be weakly exogeneous as the null hypothesis cannot be rejected in equations with 1_rapeseed_oil and 1_palm_oil and the results indicate that biodiesel prices respond to a price change of vegetable oils. The results clearly show that

\footnotetext{
1 According to Zahran (2013) non-profit relationship exists between the variables, if the speed of mean reversion for both equations would have opposite signs, where positive profits will cause biodiesel price to fall and vegetable oil price to rise sufficiently eliminating profit.
}

the tested variables cannot be treated as weakly exogenous in the equation with soybean oil and the long-term relationship between the variables is simultaneous. Looking at co-integration vector $\beta$, the following price linkage is detected: a $1.00 \%$ increase in rapeseed oil price would lead to $0.86 \%$ increase in biodiesel price and $1.00 \%$ increase in soybean price would cause a rise of $0.73 \%$ in biodiesel price. Additionally, the value of 0.72 expresses price transmission elasticity indicating that increase in palm oil price by $1.00 \%$ would result in rise of biodiesel by $0.72 \%$. To sum up, relationship between the pairs of considered series is not simultaneous and indicates only one-way relation with the impact of vegetable oil prices on the biodiesel prices in case of rapeseed and palm_oil. However, there is an evidence of simultaneous relationship between biodiesel and soybean oil prices. Similarly, Bentivoglio (2016) points out that the positive relationship between biodiesel and rapeseed oil prices is not surprising given the relevance of feedstock costs on the total costs for producing biodiesel $(80 \%)$. Hence, the biodiesel sector reacts to price changes in the agricultural commodity market.

Busse et al. (2010) state that the international vegetable oil markets were found to play a more important role than the biodiesel market during 
the food crisis that was indicated by the strong influence of past vegetable oil price changes and the missing reaction to past biodiesel price changes. Diagnostic checks show that null hypothesis of homoscedasticity is accepted, the null hypothesis of no autocorrelation is not rejected as well and the regression models account for approximately $28 \%$ of the variance in all three equations (Table 4).

The VECM results indicate that crude oil prices have significant impact on vegetable oil prices and biodiesel prices and appear to be weakly exogeneous demonstrating that vegetable oil and biodiesel prices are affected by crude oil prices (Table 5). More specifically, $1.00 \%$ increase in crude oil prices would lead to $0.91 \%$ increase in rapeseed oil price, $1.47 \%$ in soybean oil prices and $0.57 \%$ in palm oil prices. In case of biodiesel prices, an increase in the crude oil prices by $1.00 \%$, the biodiesel prices would rise by $0.96 \%$. Banse et al. (2011) consider that high feedstock prices make biofuels less profitable, as does a low oil price and the higher the crude oil price the more competitive biofuel crops become versus petroleum production. Similarly, Busse et al. (2010) show stable long-run relationship between crude oil and biodiesel as well as between biodiesel, rapeseed oil and soybean oil, however, the price adjustment behaviours change in different phases of the market development. Crude oil prices adjust slower to deviations from the long run equilibrium in comparison to the other examined series. Error correction coefficients have opposite signs in the equation with 1_rapeseed_oil and 1_palm_oil indicating there is only one equilibrium relation between the variables. The examined models are considered as stable and reliable due to the fact that null hypotheses of homoscedasticity and no autocorrelation are accepted.

\section{Conclusion}

The paper analyses price interdependencies between energy and vegetable oil prices. The research is conducted on the basis of price transmission technique - cointegration test and vector error correction model. Co-integration test provides evidence of long-run relationship between prices of biodiesel, crude oil and selected vegetable oils used for biodiesel production

\begin{tabular}{lccc}
\hline & I_rapeseed_oil & I_soybean_oil & I_palm_oil \\
\hline Constant & $0.223640 * * *$ & $0.262872 * * *$ & $0.240115^{* * *}$ \\
Cointegration vector $\boldsymbol{\beta}$ & -0.86371 & -0.73205 & -0.72296 \\
Adjustment coefficient $\boldsymbol{\alpha}$ & 1_rapeseed_oil & 1 soybean_oil & 1 palm_oil \\
& -0.026438 & $-0.087938^{* *}$ & 1 biodiesel \\
& 1_biodiesel & 1 biodiesel & $-0.10196 * * *$ \\
R-squared & $0.14802 * * *$ & $-0.122024 * * *$ & 0.286434 \\
ARCH & 0.287125 & 0.268599 & p-value 0.69611 \\
Autocorrelation & p-value 0.848118 & p-value 0.813032 & p-value 0.225 \\
\hline
\end{tabular}

Notes: $* * *$ significance at $1 \%$ level, $* *$ significance at $5 \%$ level

Source: own processing

Table 4: VECM estimation - biodiesel prices and vegetable oil prices.

\begin{tabular}{lcccc}
\hline & I_rapeseed_oil & I_soybean_oil & l_palm_oil & l_biodiesel \\
\hline Constant & $0.133214 * * *$ & $0.293672 * * *$ & $0.240115^{* * *}$ & $0,150813 * * *$ \\
Cointeg. vector $\boldsymbol{\beta}$ & -0.90854 & -1.4678 & -0.57188 & -0.95799 \\
Adjustment coefficient $\boldsymbol{\alpha}$ & 1_rapeseed_oil & 1_soybean_oil & 1_palm_oil & 1_biodiesel \\
& $-0.14622 * * *$ & $0.13739 * * *$ & $-0.095694 * *$ & $-0.11690 * * *$ \\
& 1_crude_oil & 1 crude_oil & 1_crude_oil & 1 crude_oil \\
R-squared & 0.052298 & 0.099254 & 0.066228 & -0.0083727 \\
ARCH & 0.340494 & 0.352621 & 0.412069 & 0.236620 \\
Autocorrelation & p-value 0.318208 & p-value 0.324158 & p-value 0.70116 & p-value 0.910583 \\
\hline
\end{tabular}

Notes: $* * *$ significance at $1 \%$ level, $* *$ significance at $5 \%$ level

Source: own processing

Table 5: VECM estimation - crude oil prices and vegetable oils. 
in Germany. The results suggest, as expected, that increase in crude oil prices would lead to an upward trend in the vegetable oils used for biodiesel production, thus influencing biodiesel prices as well. These results are in line with Ghaith and Awad (2011) who proved the co-integration between crude oil and biofuel crop prices which might be at least a signal of the linkage between the biofuel industry and crude oil prices. The relationship between the biodiesel - rapeseed oil and biodiesel - palm oil is not simultaneous and indicates only one-way relation with the impact of vegetable oil prices on the biodiesel prices. On the other hand there is an evidence of simultaneous relationship between biodiesel and soybean oil prices. The findings of Busse et al. (2010) also demonstrate the strong evidence for co-integration between German biodiesel and crude oil prices.

Our research provides better insight of interacting price behaviour of energy prices and vegetable oils used as a feedstock for biodiesel production in the EU biodiesel market and contributes also to the biofuel and food price debate. Based on our research we conclude that crude oil prices could be considered as an acceptable predictor of food commodity price changes; however, there is evidence that biofuel prices do not determine food prices (except the impact of biodiesel on soybean oil price). In principle, enhanced biodiesel demand leads to increase in production of biofuel crops and competition for land, thus the concept of cultivation crops for non-food uses results in less land availability for food and higher agricultural prices whereas food prices are less impacted by biofuels production (Vasile et al., 2016). An alternative is to look for other feedstocks (e.g. lignocellulosic crops) and use marginal land for growing biofuel crops without displacing existing crops. The second generation biofuels are considered to be more cost-effective and more effective in reducing greenhouse gas emissions. Additionally, Bobadilla et al. (2017) show the high quality of the biodiesel produced from waste cooking oil hence waste cooking oil is a potential replacement for vegetable oils in the production of biodiesel. This study can be extended by investigation of the patterns of land use for biofuel feedstock in order to find out further interdependences between the agri-food sector and biodiesel industry using the land for the crop production for non-food purposes.

\section{Acknowledgements}

This work was supported by Grant Agency SUA in Nitra under project no. 04-GA SPU-16.

Corresponding author:

Ing. Zuzana Lajdová, PhD.

Department of Economics, Faculty of Economics and Management

Slovak University of Agriculture in Nitra, Tr. A Hlinku 2, 94976 Nitra

E-mail: zuzana.lajdova@gmail.com

\section{References}

[1] Bakhat, M. and Würzburg, K. (2013) "Price relationships and Crude oil and Food Commodities", Economics for energy, Alcoa Advancing Sustainability Initiative to Research and Leverage Actionable Solutions on Energy and Environmental Economics, WP FA06/2013. ISSN 2172-8437.

[2] Banse, M., van Meijl, H., Tabeau, A, Woltjet, G., Hellmann, F. and Verburg, P. H. (2011) "Impact of EU biofuel policies on world agricultural production and land use", Biomass and Bioenergy, Vol. 3, pp. 2385-2390. ISSN 0961-9534.

[3] Barnwal, B. K. and Sharma, M.P . (2005) "Prospects of biodiesel production from vegetable oils in India”, Renewable and Sustainable Energy Reviews, Vol. 9, No. 4, pp. 363-378. ISSN 1364-0321. DOI 10.1016/j.rser.2004.05.007.

[4] Bentivoglio, D., Finco, A., Bacchi, M. R. P and Spedicato, G. (2014) "European biodiesel market and rapeseed oil: Which impact on agricultural food prices?", Int.. J. Global Energy Issues - Special Issue on Bio-Energy, Economics and Policy, Vol. 37, No. 5/6.

[5] Bentivoglio, D. and Rasetti, M. (2015) "Biofuel sustainability: review of implications for land use and food price", Rivista di Economia Agraria, Vol. 70, No. 1, pp. 7-31. ISSN 0035-6190. DOI 10.13128/REA-16975. 
[6] Bentivoglio, D. (2016) "Biofuel-food market interaction: exploring the price link in the European and Brazilian context", Rivista di Economia Agraria, Vol. 71, No. 1, pp. 570-579. ISSN 0035-6190. DOI 10.13128/REA-18673.

[7] Bobadilla, M.C. et al. (2017) “An Improvement in Biodiesel Production from Waste Cooking Oil by Applying Thought Multi-Response Surface Methodology Using Desirability Functions", Energies, Vol. 10, No. 1. ISSN 1996-1073. DOI 10.3390/en10010130.

[8] Burakov, D. (2017) "Do Sunspots Matter for Cycles in Agricultural Lending: A VEC Approach to Russian Wheat Market", Agris on-line Papers in Economics and Informatics, Vol. 9, No. 1, pp. 17-31. ISSN 1804-1930. DOI 10.7160/aol.2017.090102.

[9] Busse, S. and Ihle, R. (2009) "German Rapeseed Oil and Biodiesel Pricing under Changing Market Conditions: A Markov-switching Vector Error Correction Model Approach". International Association of Agricultural Economists Conference, Beijing, China. [Online]. Available: http://ageconsearch.umn.edu/bitstream/51032/2/Busse_173.pdf [Accessed: 15 May 2017].

[10] Busse, S., Brümmer, B. and Ihle, R. (2010) “Integration of Biodiesel and Crude Oil Prices". [Online]. Available: http://oega.boku.ac.at/fileadmin/user_upload/Tagung/2010/Short_paper_2010/13 Busse_et_al-OEGA_TB_2010.pdf [Accessed: 15 May 2017].

[11] Busse, S., Brümmer, B. and Ihle, R. (2010) “The Pattern of Integration between Fossil Fuel and Vegetable Oil Markets: The Case of Biodiesel in Germany". [Online]. Available: http://citeseerx.ist.psu.edu/viewdoc/.

[12] Capitani, D. H. D. (2014) "Biofuels versus food: How much Brazilian ethanol production can affect domestic food prices? “. Agricultural \& Applied Economics Association's 2014 AAEA Annual Meeting, Minneapolis. [Online]. Available: http://ageconsearch.umn.edu/bitstream/170267/2/ AAEA\%202014_Capitani_paper\%204941.pdf [Accessed: 15 May 2009].

[13] Ciaian, P. and Kancs, A. (2011) "Interdependencies in the energy-bioenergy-food price systems: A cointegration analysis", Resource and Energy Economics, Vol. 33, No. 1, pp. 326-348. ISSN 0928-7655. DOI 10.1016/j.reseneeco.2010.07.004.

[14] Chen, B. and Saghaian, S. (2015) "The Relationship among Ethanol, Sugar and Oil Prices in Brazil: Cointegration Analysis with Structural Breaks“. Southern Agricultural Economics Association's 2015 Annual Meeting, Atlanta, Georgia. [Online]. Available: http://ageconsearch.umn.edu/ bitstream/196788/2/The\%20Relationship\%20among\%20Ethanol,\%20Sugar\%20and\%20Oil\%20 Prices\%20in\%20Brazil\%20Cointegration\%20Analysis\%20with\%20Structural\%20Breaks.pdf [Accessed: 3 May 2017].

[15] Demirbas, A. (2008) "Biofuels sources, biofuel policy, biofuel economy and global biofuel projections", Energy Conversion and Management, Vol. 49, No. 8, pp. 2106-2116. ISSN 0196-8904. DOI 10.1016/j.enconman.2008.02.020.

[16] Blanco, F. M., Burrell, A., Gay, S., Henseler, M., Kavallari, A., M'barek, R., Pérez, D. I. and Tonini, A. (2010) "Impacts of the EU Biofuel Target on Agricultural Markets and Land Use. A Comparative Modelling Assessment", JRC European Commission. ISSN 1018-5593. DOI 10.2791/45105.

[17] Gaith, Z., Awad, M. I. (2011) "Examing the long term relationship between crude oil and food commodity prices: co-integration and causality“, International Journal of Economics and Management Sciences, Vol. 1, No. 5. pp. 62-72.

[18] Hao, N., Colson. G., Karali, B. and Wetzstein, M. (2013) "Food before Biodiesel Fuel?". Southern Agricultural Economics Association (SAEA) Annual Meeting, Orlando, Florida, 3-5 February 2013. [Online]. Available: http://ageconsearch.umn.edu/bitstream/143078/2/Food\%20before $\% 20$ Biodiesel\%20Fuel.pdf [Accessed: 10 May 2017].

[19] Hassouneh, I., Serra, T., Goodwin, B. K. and Gil, J. M. (2012) "Non-parametric and parametric modelling of biodiesel, sunflower oil, and crude oil price relationships", Energy Economics, Vol. 34, No. 5, pp.1507-1513. ISSN 0140-9883. DOI 10.1016/j.eneco.2012.06.027. 
[20] International Energy Agency (2015) “Biofuels Quota Act". [Online]. Available: https://www.iea.org/ policiesandmeasures/pams/germany/name-38694-en.php [Accessed: 25 April 2017].

[21] Issariyakul, T. and Dalai, A. K. (2014) "Biodiesel from vegetable oils“, Renewable and Sustainable Energy Reviews, Vol. 31, pp. 446-471. ISSN 1364-0321. DOI 10.1016/j.rser.2013.11.001.

[22] Jena, P. K. (2016) "Commodity market integration and price transmission: Empirical evidence from India“, Theoretical and Applied Economics, Vol. 23, No. 3, pp. 283-306.

[23] Kristoufek, L., Janda, K. and Zilberman, D. (2012) "Mutual Responsiveness of Biofuels, Fuels and Food Prices". CAMA Working paper 38/2012, Centre for Applied Macroeconomic Analysis, Australian National University. [Online]. Available: https://papers.ssrn.com/sol3/papers. cfm?abstract_id=2294754 [Accessed: 23 April 2017].

[24] Kristoufek, L., Janda, K. and Zilberman, D. (2013) "Price transmission between biofuels, fuels, and food commodities", Biofuels, Bioproducts and Biorefining, Vol. 8, No. 3, pp. 362-373. ISSN 1932-1031. DOI 10.1002/bbb.1464.

[25] Knothe, G., Dunn, R. O. and Bagby, M. O. (n.d) "Biodiesel: The Use of Vegetable Oils and Their Derivatives as Alternative Diesel Fuels". Oil Chemical Reserach. National Center for Agricultural Utilization Research. U.S. Department of Agriculture. [Online]. Available: http://journeytoforever. org/biofuel_library/VegetableOilsKnothe.pdf [Accessed: 3 May 2017].

[26] Lajdova, Z., Kapusta, J. and Bielik, P. (2015) "Price linkages between biofuels and food commodities", ICABR 2015. Brno: Mendel University, pp. 571-579. ISBN 978-80-7509-379-0.

[27] Naik, S. N., Goud, V., Rout, P.K and Dalai, A. K. (2010) "Production of first and second generation biofuels : A comprehensive review", Renewable and Sustainable Energy Reviews, Vol. 14, No. 2, pp. 578-597. ISSN 1364-0321. DOI 10.1016/j.rser.2009.10.003.

[28] Natanelov, V., Mckenzie, A. M. and Huylenbroeck, G. (2013) "Crude oil-corn-ethanol - nexus: A contextual approach", Energy Policy, Vol. 63, pp. 504-513. ISSN 0301-4215. DOI 10.1016/j.enpol.2013.08.026.

[29] Peri, M. and Baldi, L. (2010) "Vegetable oil market and biofuel policy: An asymmetric cointegration approach“, Energy Economics, Vol. 32, pp. 687-693. ISSN 0140-9883. DOI 10.1016/j. eneco.2009.09.004.

[30] Pires, A. and Schechtman, R. (2010) "International Biofuels Policies". Ethanol and Bioelectricity. Sugarcane in the Future of the Energy Matrix. [Online]. Available: http://sugarcane.org/resourcelibrary/books/International\%20Biofuels\%20Policy.pdf [Accessed: 3 May 2017].

[31] Serra, T., Zilberman, D., Gil, J. M. and Goodwin, B. K. (2011) "Nonlinearities in the U.S. corn-ethanol-oil-gasoline price system“, Agricultural Economics, Vol. 42, No. 1, pp. 35-45. E-ISSN 1574-0862. DOI 10.1111/j.1574-0862.2010.00464.x.

[32] Shereena, K.M. and Thangaraj, T. (2009) "Biodiesel: an Alternative fuel Produced from Vegetable Oils by Transesterification”, Electronic Journal of Biology, Vol. 5, No. 3, pp. 67-74. ISSN 1860-3122.

[33] Vasile, A. J., Andreea, I. R., Popescu, Ch. H., Elvira, N. and Marian, Z. (2016) 'Implications of agricultural bioenergy crop production and prices in changing the land use paradigm - The case of Romania“, Land Use Policy, Vol. 50, pp. 399-407. ISSN 0264-8377. DOI 10.1016/j. landusepol.2015.10.011.

[34] Yu, T., Bessler, D. A. and Fuller, S. (2006) "Cointegration and Causality Analysis of World Vegetable Oil and Crude Oil Prices", Agricultural Economics Association. Annual Meeting. California. [Online]. Available: http://ageconsearch.umn.edu/bitstream/21439/1/sp06yu02.pdf [Accessed: 23 April 2017].

[35] Zahran, H. (2013) “Biodiesel profitability and linkages to the soybean oil market". University of Illinois at Urbana-Champaign. [Online]. Available: https://www.ideals.illinois.edu/handle/2142/45274 [Accessed: 28 April 2017]. 